\title{
Covid-19 Salgını Döneminde Kamu Çalışanlarının Örgütsel Sessizlik Davranışlarının Kararlara Katılma ve İş Özerkliği Uygulamaları Üzerine Etkisi
}

The Effect of Organizational Silence Behaviors of Public Employees on Participation in Decisions and Professional Autonomy Practices During the Covid-19 Pandemic Period

\section{Perihan GöZüM}

Dr. Öğr. Üyesi., Ardahan Üniversitesi,

Çıldır MYO, Hukuk Bölümü,

perihangozum@gmail.com

https://orcid.org/0000-0003-1174-8500
Makale Başvuru Tarihi: 17.04.2021

Makale Kabul Tarihi: 23.06.2021

Makale Türü: Araştırma Makalesi

\section{Anahtar \\ Kelimeler: \\ İş Özerkliği, \\ Kamu Çalışanları, \\ Kararlara \\ Katılma, \\ Covid-19 Salgını, \\ Örgütsel Sessizlik \\ Davranışl,}

Keywords:

Professional

Autonomy Practices,

Public Employees,

Participation in

Decisions,

Covid-19 Pandemic

Period,

Organizational

Silence Behavior,

\section{ÖZET}

Bu araştırmada Covid 19 salgını döneminde kamu çalışanlarının örgütsel sessizlik davranışlarının kararlara katılma ve iş özerkliği uygulamaları üzerine etkileri incelenmeye çalışılmıştır. Araştırmanın sonuçlarına bakıldı̆̆ında Kamu çalışanlarının örgütsel sessizlik düzeyi ile karara katılma düzeyleri arasında pozitif yönde zayıf bir iliş̧i bulunduğu görülmektedir. Aynı şekilde razı olma sessizliği ile karara katılma düzeyleri arasında ve savunma sessizliği ile karara katılma düzeyleri arasında da pozitif yönde zaylf bir ilişki bulunduğu görülmektedir. Örgütsel sessizlik düzeyi ile iş özerkliği düzeyleri arasında pozitif yönde zaylf bir iliş̧i bulunduğu görülmektedir. Aynı şekilde razı olma sessizliği ile iş özerkliği düzeyleri arasında ve savunma sessizliği ile iş özerkliği düzeyleri arasında da pozitif yönde zayıf bir ilişki bulunduğu görülmektedir. Kamu çalışanlarının örgütsel sessizlik davranışlarını hizmet süresi değişkenine göre değerlendirdiğimiz de razı olma sessizliği boyutu için hizmet süresi 11-15 yıl olan çalışanların ve 16 yıl ve üzeri olan çalışanların örgütsel sessizlik davranış düzeylerinin hizmet süresi 0-5 yıl arası olanlara göre anlamlı bir şekilde daha yüksek olduğu görülmüş̧ür. Örgütsel sessizlik davranışlarını kendini tanımlama değişkenine göre değerlendirdiğimiz de razı olma sessizliği boyutu için sessiz ve sakin olan çalışanların düzeylerinin sosyal ve dışa dönük olanlara göre anlamlı bir şekilde daha yüksek olduğu görülmüştür.

\section{ABSTRACT}

In this study, it was attempted to examine the effects of organizational silence behaviors of public employees on participation in decisions and professional autonomy practices during the Covid-19 pandemic period. Looking at the results of the study, it was seen that there was a positive and weak relationship between the organizational silence level of public employees and the level of participation in decisions. Similarly, it was determined that there was a positive and weak relationship between the consent silence and their levels of participation in the decision, and between the levels of defense silence and participation in the decision. It was seen that there was a positive and weak relationship between organizational silence and professional autonomy levels. Likewise, there was a positive and weak relationship between the silence by consent and the levels of professional autonomy, and between the levels of defensive silence and professional autonomy. When the organizational silence behaviors of public employees were evaluated according to the duration of service variable, it was seen that for the silence by consent behavior dimension, the organizational silence behavior levels of employees with a service period of 11-15 years and employees with a service period of 16 years and above were significantly higher than those whose service periods were between 0-5 years. When organizational silence behaviors were evaluated according to the variable of self-identification, it was observed that for the silence by consent dimension, the levels of employees who were quiet and calm were significantly higher than those who were social and extroverted. 


\section{GIRISs}

Araştırmanın temel bakış açısı Covid-19 salgını döneminde kamu çalışanlarının örgütsel sessizlik davranışlarının kararlara katılma ve iş özerkliği uygulamaları üzerine etkileri incelenmeye çalışılmıştır. Uluslararası ulaşım yoluyla hızla ülkemizi de etkisi altına almıştır. Hayatın normal rutinini bozan toplumsal dengeleri alt üst eden ve kendine özgü toplumsal kuralları dayatan bu salgının kamu çalışanlarımızı da olumsuz yönde etkilemektedir.

Salgın dünyada Çin Halk Cumhuriyetinin Wuhan şehrinde 31 Aralık 2019 tarihinde meydana gelmiştir (WHO, 2020a). Öncelikle, hastalık Çin ve çevresi merkezli iken, zamanla tüm bütün dünyaya yayılmıştır. "Dünya Sağllk Örgütü (DSÖ) tarafindan hastalık 11 Mart 2020 tarihinde pandemi olarak ilan edilmiştir" (WHO, 2020b). Ülkemizde 10 Mart 2020 tarihine ilk vaka kayıtlara girmiştir (T.C. Sağlık Bakanlığı, 2021). Salgının ilk görüldüğü andan bugüne kadar dünyada 94.501.892, Türkiye'de 2.380 .665 kişide vaka tespit edilmiştir. Dünyadaki Covid-19'a bağlı ölüm sayısı 2.022.279 iken Ülkemizde ölüm sayısı 23.832'dir. Ancak ilgili sayılar halen artmaya devam etmektedir (WHO, 2020c).

Pandemiler etki ve sonuçları itibariyle öngörülemeyen vakalar kategorisindedir. Salgınların insan ve hayvan kitlelerini kapsayıcı ölümcül sonuçları olmaktadır. Bu durum toplum yaşamını geri döndürülemeyecek şekilde değiştirmektedir. Salgının başlangıcı küresel bir milat olma özelliğine sahiptir (Aslan, 2020:48). Tarihsel süreçte dünya üzerinde birçok salgın ortaya çıkmıştır. Bu salgınlar bölgesel ve kimi zaman küresel ölçekte geniş bir coğrafi alanı etkisi altına almıştır. Günümüzde ise bu tür salgınlar çok daha hızlı ve geniş bir coğrafyayı etkisi altına alabilmektedir. Bunun temel nedeni ise insanların küresel düzeydeki yüksek hareketlilik hızıdır (Turan ve Hamza Çelikyay, 2020:4). Koronavirüsler ve Covid-19'un temel özelliklerinden kısaca bahsedilecek olursa (Zhu vd., 2020:2);

"Coronavirüsler (CoV) yaygın görülen ama genellikle kendini sinırlayan, bu sebeple de hafif enfeksiyon tablolart ile seyreden bir virüs ailesidir. Aynı virüslerin Orta Doğu Solunum Sendromu (MERS) ve Ă̆ır Akut Solunum Sendromu (SARS) gibi çok ciddi enfeksiyonlara yol açtıkları bilinmektedir. Coronavirüsler insanlarda bulunan ve insandan insana kolayca bulaşabilen $\mathrm{HCoV}$ 229E, HCoV-OC43, HCoV-NL63, HKU1-CoV gibi alt tipleri olduğu gibi, hayvanlarda bulunan ve insana geçerek ağır hastalık oluşturan SARS-CoV, MERS- CoV gibi alt tipleri de mevcuttur."

Covid 19 salgını döneminde kamu çalışanlarının örgütsel sessizlik davranışlarında susturulmuş veya sessiz kalmaya zorlanmış olmak üzere iki temel davranış kalıbı temelinde toplanır. Çalışanın iş güvenliği ve istihdamı açısından susmayı daha güvenli yol olarak görmesi ve diğerlerinin fikir beyan etmesine müsaade edilmez. Örgütlerde, örgütsel sessizliği tetikleyen iç ve diş nedenler olabilmektedir (Blackman ve Sadler-Smith, 2009:571; Özdoğru ve Aydın, 2016:359). İş özerkliği; "görevin, işsin planlanmasında ve yürütülmesinde kullanılacak prosedürlerin belirlenmesinde önemli ölçüde özgürlük, bağımsızlı ve takdir yetkisi sağlaması"' şeklinde tanımlanmıştır (Hackman ve Oldham, 1975:161). Özerklik çalışanların tatminini, bağlılığını ve motivasyonunu etkileyen önemli bir iş özelliğidir (Spector, 1986:1007).

\section{2. ÖRGÜTSEL SESSIZLIIK}

Çalışanların örgütlerde, yapmaları gereken çalışma alanlarında ya da kurumun çalışmaları ile ilgili fikir ve önerilerini söyleyememe veya cesaret edememe davranışı olarak tanımlanmaktadır (Alparslan ve Kayalar, 2012:137). Örgütsel sessizlik, pasif olmayan, kasıtlı ve amaca yönelik bir yaklaşımdır (Benli ve Cerev, 2017:413). Bu davranış, kimi zaman sadakatin bir göstergesi gibi gözüküyor olsa da esasen çalışanların bilgi, fikir, yaklaşım ve düşüncelerini muhtelif sebeplerden dolayı gizlemesi, açığa çıkarmamasıdır (Bay ve Bayraç, 2021:501). Örgütteki iş görenlerin neden sessiz kaldıkları ve böyle bir durumda nasıl sessizliği çözümleyecekleri konusunda çok sayıda araştırmalar yapılmıştır. Bu araştırmaların sonucunda sessizlikle ilgili farklı teoriler ve fikirler geliştirmişlerdir (Vakola ve Bouradas, 2005:443).

- Fayda Maliyet Analizi: Kişilerin, sessiz kalma veya konuşmak istemelerine karar vermeleri sırasında fayda maliyet analizi kullandıkları görülmüştür. Kişiler konuşmadan sağlayacakları faydanın, konuşma

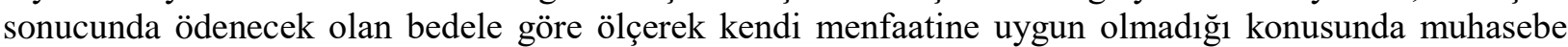
yaparlar (Premeaux ve Bedeian, 2003:1539). Sessizleşme ya da ses çıkarma kavramlarını akılcı bir tutuma bağlıdır. Bireyler ortaya çıkacak olan olumsuz sonuçları değerlendirmekte ve farklı sonuçları fayda- maliyet analizi yapmaktadır (Kolarska ve Aldrich, 1980:45). 
- Beklenti Teorisi: Vroom'un Beklenti Teorisi; bir tutumun oluşmasını sağlayan etmenler, kişinin kendine has özellikleri ile çevresel etmenlerin etkisiyle beraber tespit ve kanalize edilir. Kişilerin psikolojisinde dünyaya bakış açıları, edindikleri tecrübe, çalışacakları birimden beklentileri vardır. Bütün bu faktörler kişinin çalıştığı birime nasıl katkı sağlayacağını belirler (Eren, 2000:321). Bu işleyiş̧e göre kilit nokta ise, kişilerin, kaynağı motivasyondan oluşan davranışlar sergilemeden önce oluşturmuş oldukları beklenti duygularıdır (Bateman ve Zeithaml, 1990:25).

- Sessizlik Sarmalı: Sessizlik Sarmalı, bir düşünce ortaya atmadan önce bu düşüncenin kamu desteği seviyesinde değerlendirilme olayıdır. Sessizlik sarmalı kavramı, insanlar sayı çokluğunu yakalamadan kendilerine güvenilmeyeceğini ya da kendi düşüncelerinin ciddiye alınmayacağını düşündükleri için, düşüncelerini ifade etmekten çekindiklerini açıklar. İnsanlar sayıca az olduklarını düşündüklerinde, kendi düşüncelerini ve fikirlerini gizleme ihtiyacı hissederler (Çakıc1, 2007:147). Sessizlik sarmalı iş görenlerin örgüt içerisinde seslerini çıkarmaları için diğer meslektaşlarından yardım almaları gerektiğini vurgularken, meslektaşlarından yardım alamayan iş görenlerin ise doğru olmayan bir cevap verme ya da sessiz kalma gibi bir tercihte bulunacaklarını vurgulamıştır. Sessizlik sarmalının bulunduğu gruplarda, örgütsel iyileşmeler konusunda iş görenlerin açık ve dürüst bir biçimde tartışmalar gerçekleştirmeleri mümkün olmayabilir. Bu duruma yol açan ise dişlanma tehdidi ve korkusudur (Bowen ve Blackmon, 2003:1395).

- Kendini Uyarlama: Teori, insanların birbirleri arasındaki bağlarını kendilerini ön plana çıkarmanın, kamu sektöründeki yansımasını gözleme, yavaş yavaş oluşumunu tamamlamaya ve kontrol etmenin seviyesi ile doğru orantılıdır (Greenberg ve Baron, 2003:411). Adapte olabilme seviyesi fazla olan bireyler, toplumda saygın bir statü elde etmek için kendi sosyal davranışlarının farkında olup düzeltme kabiliyeti olan ve ortama ait bilgileri kabul eden bireylerdir. Aksine kendini uyarlama seviyesi az olan insanlarsa, sahip oldukları duyguları, davranışları, düşünceleri ve yargıları ortaya koyma yönünde bir meyil göstermektedirler. Adapte olabilme seviyesi az olan insanlar, kişisel gözlemleme seviyesi fazla olan bireylere nazaran daha açık ve net bir biçimde konuşmaktadırlar (Premeaux ve Bedeian, 2003:1541).

Örgütsel sessizlik, kendi içerisinde "kabullenici", "korunmacl" ve "korumacl" olarak üç farklı türe ayrılmaktadır. Örgütsel sessizlik türleri kısaca şunlardır;

- Kabullenici Sessizlik: Kabullenici sessizlik, örgütteki gelişmeler karşısında razı olmaya dayanarak; bilgi, görüş, fikir ve düşüncelerin söylemekten çekinilmesi olarak tanımlanmaktadır (Karacaoğlu ve Cingöz, 2009:22). Kabullenici sessizlik türünü benimseyen çalışanlar, örgütün gerekli gördüğü koşulları olduğu gibi kabul edip var olan durumu değiştirme yoluna gitme konusunda bir bilinç eşiği oluşmamış kişilerdir. Kabullenici bu durum çalışanlara güven hissi verdiğinden dolayı farklı alternatifler arayışına girme ve koşulları değiştirme gibi bir davranış içine girmeyip sessiz kalmayı kabul ederler (Blensinkopp ve Edwards, 2008:185).

- Korunmacı Sessizlik: Korku insanların algılarını, düşünme şekillerini ve davranışlarını etkileyen, fakat önemsenmeyen güçlü ve sık rastlanan bir duygudur (Gephart vd., 2009). Örgütsel sessizliğin anahtarı durumunda olan kaygı ve korku duygusu işgörenlerin psikolojik olarak örgüte güvenmemelerinin temeli olarak açıklanabilir (Edmonson, 1999:352). Korumacı sessizlik, çalışanların herhangi bir durum ya da sorun karşısında düşüncelerini dile getirdikleri zaman ortaya çıkması beklenilen tepkilerden korktukları için kendilerini koruyabilmeleri için fikir ve düşüncelerini kendilerine saklamaları olarak tanımlanır. Bu sessizlik türünün temeli, çalışanların kendini koruma isteğidir. $\mathrm{Bu}$ nedenle bireyler bilinçli olarak düşüncelerini sessizlikle saklayıp gerçek düşüncelerini ortaya koymazlar (Dyne vd., 2003:1362).

- Korumacı Sessizlik: Korumacı sessizlik, özgeci bir davranış barındırmaktadır. Özgeci davranış, çeşitli durumlarda karşılık ya da ödüllendirme beklentisi olmadan başka birine yardımcı olma olarak ifade edilmektedir. Bireylerin diğer çalışanları önemsemesi ya da birbirleriyle olan çıkarlarına dayanarak, örgütüne veya diğer çalışanlara faydalı olmak açısından, belli başlı bir olay hakkında düşünce, bilgi veya fikirlerini dile getirmemesi şeklinde tanımlanmaktadır (Karacaoğlu ve Cingöz, 2003:23).

\section{KARARLARA KATILMA VE İ̧̧ ÖZERKLİĞİ}

Örgütte bulunan kişilerin kararlara katılması, karar verme sürecinin paydaşlar tarafından sürece katılması olarak ifade edilebilir (Ural ve Aksay, 2008:435). Yönetim biliminde Karar verme sürecinin daha nitelikli hale getirilmesi hedefine ulaşmak için birtakım araştırmalar yapılmış ve ortaya "iş görenin karara katılması" 
yaklaşımı ortaya çıkmıştır (Uras, 1995:123). Çalışanların kararlara katılması kendini ilgilendiren yönetimsel alanda kararların oluşması ve problem çözmede takım çalışmasında katılımcı bir üye olarak etkin rol alması mantığ temelinde şekillenir (Başaran, 2000:115).

Kararlar örgütün amaçlarını gerçekleştirmeye uygun oldukları zaman gerçekçi ve etkilidir, bu sebeple kişiler örgütlerde rasyonel karar vermeye çalışır (Hoy ve Miskel, 2012:89). Problem çözmeyle ilişkili olabilecek çözüm yollarından en uygun olanın seçilmesi karar verme sürecinde etkilidir (Tortop, 1993:95). Süreç olarak yönetim, karar verme sürecinin sağlıklı olmasına bağlıdır (Aydın, 1994:135; Songur Karakurt, 2020:26). İş görenlerin, kararlara katılma sürecinde etkin rol verilmemesi sadece süreçte yer alırken fiziksel olarak yer verilmesi, kararları etkileme gücünün olmadığına inanmasına dolayısıyla kararları en alt seviyede yâda hiç kabul etmemesi sonucunu ortaya koymaktadır (Açıköz, 1988:23).

Bireylerin örgütle bütünleşmelerinde ve onları örgütsel kararlara bağlı hale gelmelerindeki en önemli faktör karara katılma faktörüdür. Çalışanlar karar alma sürecinde, kendi ihtiyaçlarını önemseyen yöneticinin altında yöneticinin verdiği emir yerine çalışanların aldığı inisiyatif ve karar çalışanlar açısından daha fazla tatmin edicidir. Kararlara katılımda çalışanlar, deneyim ve becerilerini kullanarak verilen inisiyatifle daha iyi ve etkili çalışma imkânı sağlarlar (Balay, 2000:47).

Kavram olarak özerklik, bireyin veya örgütün, bir düşünceyi veya amacın ortaya konması ve konulan amaca ulaşılması sürecinde bağımsız olarak hareket edebilmesi olarak tanımlanmaktadır (Lumpkin ve Dess, 1996:137). Özerklik Kuramı, bireylerin iş yerlerinde içsel motivasyon kaynaklarının güçlendirilmesinde, örgütlerin çalışma özerkliklerini destekleyen faktörlere gereksinimlerinin karşılanması olarak ta ifade edilebilir (Reeve, 2006:227). İş özerkliği, çalışmada "kendi kendini kontrol etme ve uzmanlık alanı içinde hareket etme yetkisi" olarak tanımlanmaktadır (Wilensky, 1964:139; Hackman ve Oldham, 1975:162).

İş özerkliği, bireylere çalışma alanlarında karar alma veya işi tanımlama esnasında tanınan özgürlük ve inisiyatif olarak da açıklanabilir (Güleryüz ve Aydın, 2006:62). Çalışanların örgüt içindeki konum, deneyim, bilgi ve liyakat gibi donanımları örgütün amaçlarını gerçekleştirmelerinde yaşamsal bir önem taşımaktadır. Bu nedenle günümüzde, örgütler deneyimli ve nitelikli bireyleri istihdam etme, istihdam sonrası örgüte bağll1ık ve amaç birliği sağlama alanlarına önem vermektedirler. İş özerkliğine bakıldığında, çalışanların tecrübe ve becerilerinin örgüt amaçların gerçekleşmesinde işlevsel olarak motivasyon, iş tatmini ve örgütsel bağlllık gibi alanlarda örgütlere korunaklı bir alan sunmaktadır (Doğan ve Can, 2009:135).

İş özerkliği kavramının temel unsurları "bilgi", "bağımsızlık", "klyaslama yapabilme", "karar alma becerisi" ve "kararlılık" olarak beşe ayrılmaktadır. Bunlar;

- Bilgi: Bilgi faktörü ile bireylere sağlanacak iş özerkliğinin uzmanlık alanı kapsamında ve bir etki alanı dâhilinde en önemli gereksinimlerden biridir. Başka bir deyişle, bilgi kavramı, bireylerin iş özerkliğine sahip olabilmeleri açısından ihtisas alanlarının kriterlerini belirleyen eğitime, entelektüel altyapıya, liyakate ve deneyime sahip olmalarıdır (Kutanis, 2018:68).

- Bağımsızlık: Bağımsızlık kişilerin irade özgürlüğü manasına gelmektedir ve iş özerkliği tanımında bağımsızlık çalışanlar açısından önem arz etmektedir. Başka bir deyişle, bireysel yâda toplumsal bakış açısına da sahiptir (Kesici, 2014:12). İş özerkliği tanımı açısından önemli bir yere sahip olan bağımsızlık kavramı, çalışanların edindiği bilgi, deneyim ve becerilerin kişisel iradesi bağlamında kullanabilmesi olarak tanımlanabilir (Kutanis, 2018:68).

- Kıyaslama Yapabilme: Çalışanların iş özerkliği açısından ana unsurlarından biriside kıyas yapabilmesidir. Çalışanların bilgi ve deneyimlerini karşılaştıkları durum veya problemler karşısında ayrım yapabilme kapasitesi olarak da açıklanabilir. İş özerkliği olan örgütlerde örgüt üyelerinin serbest ve doğru karar alabilmesi tüm bileşenlere ve bilgileye dayalı olarak, olası sonuçları öngörerek kıyas yapabilmesine bağlıdır (Doğan ve Can, 2009:136).

- Karar Alma Becerisi: Bireylerin yapılan işlerde bireysel inisiyatif ve yetkilerini icra ederek uygulamalarıdır. İş özerkliği açısından hayati öneme sahiptir, Bireylerin kendi bilgi ve deneyimleri doğrultusunda, bireysel karar alabilmek için ihtiyaç duyulan kapasiteye sahip olabilmelerini açıklamaktadır (Kesici, 2014:13).

- Kararlılık: Çalışanların örgütsel amaçlar doğrultusunda belirlenmiş zaman aralığında iradelerinin devamlı ve istikrarlı olmasıdır. Kişilerin tecrübe edindiği öğrenimlerinin ve bu edinimlerinin ortaya koyduğu teori ve davranışları arasındaki tutarlılık ve bu tutarlılıkta ki karalılığını ifade eder (Kutanis, 2018:71). 


\section{ARAŞTIRMANIN METODOLOJISI VE UYGULANMASI}

Makalenin bu kısmında araştırmanın konusu, önemi, amacı, modeli, örneklemi, kısıtları (sınırlılıkları), veri toplama yöntemleri, veri analiz yöntemleri ve güvenilirliği detaylı olarak ele alınarak elde edilen bulgular tartış1lacaktır.

\subsection{Araștırmanın Önemi, Konusu ve Amacı}

$\mathrm{Bu}$ araştırmanın amacı, Covid-19 salgını döneminde kamu çalışanlarının örgütsel sessizlik davranışlarının kararlara katılma ve iş özerkliği uygulamaları üzerine olan etkisini belirlemek, ilgili literatüre katkı sağlamak ve araştırmacılara yeni veriler sunmaktır. İşletmelerin kurumsal başarılarının altında yatan temel faktörlerden birisi hiç şüphesiz çalışanların ortaya koyduğu emek ve gerçekleştirdikleri kurumsal katkılarıdır. Dolayısıyla üretim, dağıtım ve yönetim başta olmak üzere bazı sorunların tespit edilmesi, alternatif çözümler üretilmesi, etkinlik denetiminin gerçekleştirilmesi, yeni şartlar ve gelişmelere daha iyi uyum sağlanması konusunda sadece yöneticilerin değil, tüm çalışanların, uzmanların ve hatta hizmet/ürün alan tüketicilerin fikirleri de oldukça önemlidir. Örgütsel sessizlik ise çalışanlardan gelen bu akışın kesilmesine neden olmaktadır. Dolayısıyla bu olumsuz örgütsel davranış şeklinin nedenleri ve boyutunun tespit edilerek bu konuda çözüm önerilerinin geliştirilmesi işletmeler açısından çok önemli ve zorunlu bir faaliyettir.

Yapılan çalışma ile örgütsel sessizliğin kamu çalışanları üzerindeki etkisi "kararlara katılma" ve "iş özerkliğì" açısından ve pandemi süreci kısıtında ele alınmıştır. Çalışma sonunda elde edilen bulgular ile de bu konuda çözüm önerileri sunulmuştur. Araştırmada yapılan literatür araştırmasında "örgütsel sessizlik davranışı", "kararlara katılma", "iş özerkliği uygulamaları" ayrı ayrı başlıklarda farklı değişkenlerle yurtiçi ve yurtdışı çalışmalar yapılmış olup, örgütsel sessizlik davranışlarının kararlara katılma ve iş özerkliği uygulamaları değişkenleri kullanılarak bir arada yurtiçi ve yurtdışında yapılan bir araştırmaya rastlanmamıştır.

\subsection{Araştırmanın Modeli ve Hipotezleri}

Araştırmada "Descriptive Method" veya "Survey Research" olarak yer alan betimsel tarama modeli kullanılmıştır. Tarama modeli, araştırmanın konusunun geçmişte ya da halen var olan durumuyla ilgili hipotezleri test etmek ya da soruları cevaplamak için veri toplamayı ya da betimlemeyi sağlayan bir araştırma modelidir (Karasar, 1999). Bu araştırmada kamu çalışanlarının örgütsel sessizlik davranışlarının kararlara katılma ve iş özerkliği uygulamaları karşılaştırılmıştır. Araştırmanın ana sorusunu "Covid-19 salgını döneminde kamu çalışanlarının örgütsel sessizlik davranışlarının kararlara katılma ve işs özerkliği uygulamaları üzerine etkisi arasında nasıl bir ilişki bulunmaktadır?" şeklinde de ifade edebiliriz. Bu ana amaca yönelik olarak aşağıdaki hipotezlere cevap aranacaktır;

H1: Kamu çalışanlarının örgütsel sessizlik davranışları nasıldır?

H2: Kamu çalışanlarının karara katılma ve iş özerkliği düzeyleri nasıldır?

H3: Kamu çalışanlarının örgütsel sessizlik davranışları ile karara katılma ve iş özerkliği uygulamaları arasında nasıl bir ilişki vardır?

H4: Kamu çalışanlarının karara katılma düzeyleri diğer demografik değişkenlere göre fark göstermekte midir?

\subsection{Araştırmanın Evreni, Örneklemi ve Sınırlılıkları}

Bu araştırmanın evreni, Ankara il sınırları içerisinde yer alan Tapu ve Kadastro Genel Müdürlüğünde istihdam edilen kamu görevlilerinden meydana gelmektedir. Araştırmanın örneklemi de bu kurumda çalışan 78'i kadın ve 94'ü erkek olmak üzere toplam 172 kamu görevlisinden oluşturmaktadır. Evreni oluşturan çalışan sayısı değişkenlik göstermekle birlikte TKGM (2019) verilerine göre yaklaşı 1200 kişiden oluşmaktadır. Ancak araştırmanın yapıldığı 2020/Kasım dönemi pandemi süreci içerisinde yer almaktadır. Bu dönemde yürürlükte olan 2020/8 sayılı Cumhurbaşkanlığı Kararnamesine göre 60 yaş üstü çalışanlar ile Sağlık Bakanlığı tarafından kronik rahatsızlığı olduğu tespit edilen kişiler süresiz olarak idari izinli sayılmıştır. Ayrıca dönüşümlü çalışma uygulaması da hayata geçirilmiştir. Genelgenin yayınlandığı 2020/Mayıs döneminden itibaren salgının olumsuz 
şartları tüm dünyada etkisini devam ettirildiği için ve şartlarda bir değişkenlik öngörülemediği için resmi evren yerine fiili evren dikkate alınarak örneklem oluşturulmuştur.

Araştırmanın evren ve örnekleminin belirlenmesinde bazı kısıtlara gidilmiştir. Öncelikle bir coğrafi ve demografik kısıt söz konusudur. Bu bağlamda Ankara'da bulunan Tapu ve Kadastro Müdürlüğü çalışanları araştırmaya dâhil edilmiştir. Bu kurumun taşra teşkilatı başta olmak üzere, ilgili kurum dışındaki tüm kamu çalışanları araştırma kapsamı dışında bırakılmıştır. Yine 60 yaş üstü çalışanlar ile kronik sağlık sorunu olan çalışanlar da zorunlu olarak çalışmaya dahil edilememiştir. Ayrıca çalışma 2020 yılı Kasım ayı içerisinde yapıldığı için de bir zamansal kısıt bulunmaktadır.

\subsection{Araştırmanın Veri Toplama Araçları}

Araştırmada veri toplama aracı olarak anket formundan yararlanılmıştır. Anket formu "Sosyo-Demografik Bilgi Formu" ile "Örgütsel Sessizlik Ölçeğì" ve "Yüksek Katılımlı İs Sistemleri Ölçeği" olarak üç ana bölümden oluşmaktadır. Sosyo-demografik bilgi formu katılımcıların sosyal ve demografik bilgilerini tespit etmeye yönelik yedi adet sorudan oluşmaktadır. Ayrıca bu kısımda katılımcılara yönelik gönüllü onam formu da bulunmaktadır.

Araştırmada kullanılan Örgütsel sessizlik ölçeği, Dyne vd. (2003) tarafından geliştirilmiştir. Bu ölçek Kâhya (2013) tarafından güncellenerek geçerlilik ve güvenilirliği ölçülmüştür. Yapılan ölçümlerde Cronbach alfa güvenirlik katsayısı sırasıyla $0.88,0.88$ ve 0.80 olarak bulunmuştur. Toplam güvenilirlik katsayısı ise 0.74 olarak tespit edilmiştir. Örgütsel sessizlik ölçeğinin yap1 geçerliliğini test etmek amaciyla keşfedici faktör analizi yapılmıştır.

Araştırma kapsamında kullanılan yüksek katılımlı iş sistemleri ölçeği, Yolsal (2020) tarafından geliştirilmiştir. Yazar tarafından oluşturulan ölçeğin tamamı kullanılmamış olup, çalışmamızın kapsamı ve amacına yönelik olarak "katılımcı karar verme" ve "iş özerkliği”" faktörlerine yönelik soru grupları kullanılmıştır. YKİS ölçeği katılımcı karar verme faktörüne yönelik sorular (1-6) Parnell ve Crandall'ın (2001:526) tek boyutlu katılımc1 karar verme ölçeğinden faydalanılarak hazırlanmıştır. YKİS ölçeği iş özerkliği faktörüne yönelik sorular (3'erli) ise sirasiyla Morgeson ve Humphrey (2006), Dysvik ve Kuvaas (2011) ve Brink vd. (2016) tarafindan geliştirilen ölçeklerden alınarak geçerlik güvenirliği yapılmıştır.

Araştırma kapsamında gerekli verilerin toplanabilmesi için öncelikle Ardahan Üniversitesi Bilimsel Yayın ve Etik Kurulundan 13.11.2020 tarih ve 67796128-000-E.2000027803 sayılı etik kurul onayı alınmıştır. Etik onayına istinaden araştırma yapılacak Tapu ve Kadastro Genel Müdürlügünden idari izin alınmış ve kurum gözetiminde gönüllü katılım esasında anket uygulaması yapılmıştır. Bu kapsamda kamu çalışanları ile yüz yüze görüşülerek (Covid 19 salgınından dolayı sosyal mesafe ve maske kuralına bağlı kalarak) araştırmanın amacı açıklanıp, onamları alınarak, anket formlarını doldurmaları sağlanmıştır.

Araştırmanın örneklemini oluşturan katılımcıların seçiminde "tesadüfi olmayan örnekleme yöntemleri" arasında yer alan "kolayda örnekleme yöntemi" kullanılmıştır. Anket yapılacak kurumda idari izinli çalışanların zorunlu etkisi nedeniyle fiili evrenin çok düşük seviyede olması, birimler arasındaki resmi ve fiili çalışan sayısının oransal olarak çok farklı hale gelmesi ile salgın kaynaklı sağlık ve zamansal riskler de dikkate alınarak "kolayda örnekleme yöntemi” tercih edilmiştir.

\subsection{Araştırmanın Veri Analiz Yöntemleri ve Güvenilirliği}

Araştırmada toplanan verilerin analizi için SPSS 21.0 programından yararlanılmıştır. Araştırma verilerinin analizinde betimsel istatistikler olan aritmetik ortalama, frekans, standart sapma ve yüzde değerlerine bakılmıştır. Bu çalışma için parametrik analizlerin yapılıp yapılmayacağını belirlemek için öncelikle ölçek verilerinin normal dağılım gösterip göstermediğine bakılmıştır. Analiz sonucunda normal dağılım grafikleri ile birlikte basıklık (kurtosis) ve çarpıklık (skewness) değerleri hesaplanmıştır. Elde edilen sonuçlar şekiller aracıllğı ile aşağıda gösterilmiştir. 
Şekil 1. Razı Olma Sessizliği ve Savunma Sessizliği Boyutu İçin Normal Dağılım Grafikleri

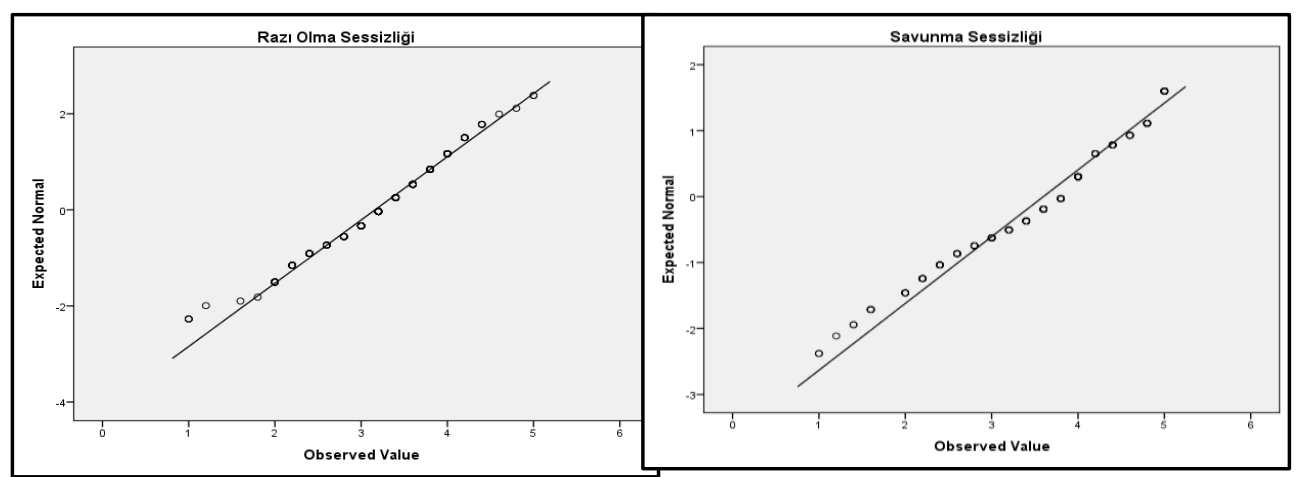

Şekil 2. Prososyal Sessizlik ve Örgütsel Sessizlik Ölçeği İçin Normal Dağılım Grafikleri

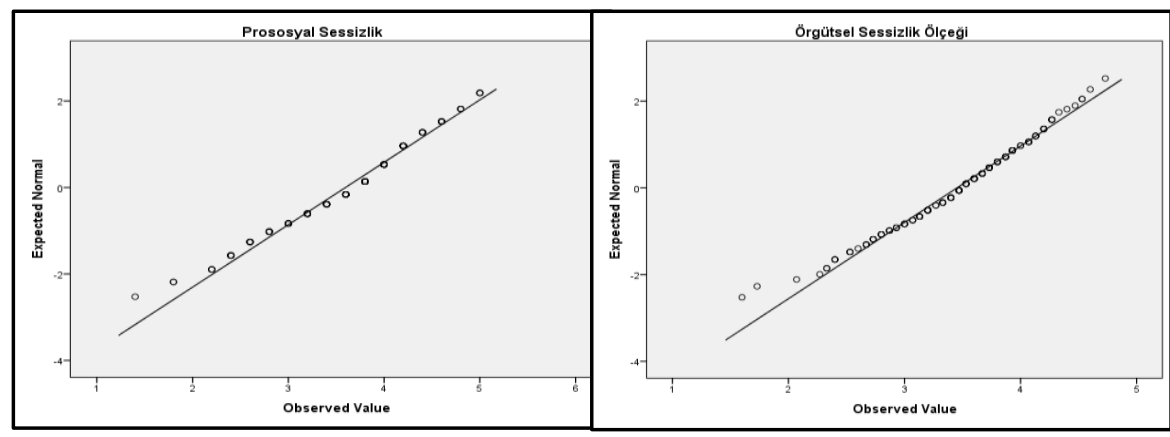

Şekil 3. Karara Katılma ve İş Özerkliği Ölçeği İçin Normal Dağılım Grafikleri

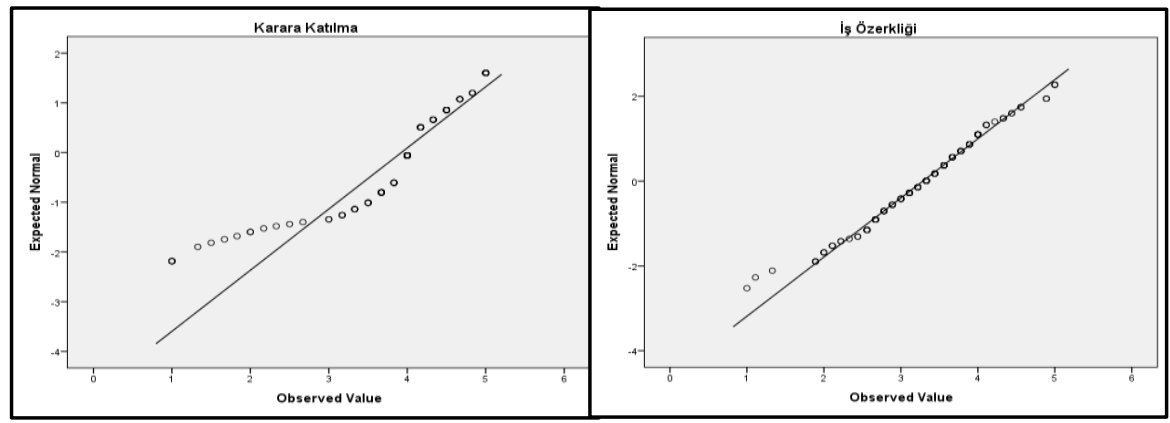

Yukarıda verilen normal dağılım grafiklerine bakıldığında Karara Katılma ölçeğinde normal dağılımdan önemli bir sapma olduğu görülmektedir. Örgütsel sessizlik ölçeği ve alt boyutları ile iş özerkliği ölçeğinde önemli ölçüde bir normal dağılım olduğu görülmektedir.

Tablo 1. Örgütsel Sessizlik Ölçeği ile Karara Katılma ve İş Özerkliği Ölçeği İçin Elde Edilen Çarpıklık ve Basıklık Değerleri

\begin{tabular}{|c|c|c|}
\hline & Skewness (Çarpıklık) & Kurtosis (Basıklı) \\
\hline Örgütsel Sessizlik Ölçeği & $-0,461$ & 0,290 \\
\hline Razı Olma Sessizliği & $-0,370$ & 0,235 \\
\hline Savunma Sessizliği & $-0,557$ & $-0,348$ \\
\hline Prososyal Sessizlik & $-0,463$ & 0,050 \\
\hline Kararlara Katılma & $-1,709$ & 3,879 \\
\hline İş Özerkliği & $-0,234$ & 0,616 \\
\hline
\end{tabular}

Normal dağılım analizi sonucunda Tablo 1'de görüldüğü gibi örgütsel sessizlik ölçeği ve alt boyutları ile iş özerkliği ölçeği için elde edilen çarpıklık ve basıklık değerleri -2 ile +2 arasında görülmektedir. Karara katılma 
ölçeğinde ise çarpıklık değerinin -2'ye yakın, basıklık değerinin ise +2 'den büyük olduğu görülmektedir. Bu verilere göre örgütsel sessizlik ölçeği ve iş özerkliği ölçeğinden elde edilen verilerin normal dağılım gösterdiğini, karara katılma ölçeğinden elde edilen verilerin normal dağılım göstermediğini söyleyebiliriz. Bu sonuçlara göre normal dağılım göstermeyen karara katılma ölçeğinde ikili karşılaştırmalar için Mann Whitnet-U testi, çoklu karşılaştırmalar için Kruskal Wallis testi kullanılmıştır. Normal dağılım gösteren örgütsel sessizlik ölçeği ve iş özerkliği ölçeğinde ise ikili karşılaştırmalar için bağımsız T testi, çoklu karşılaştırmalar için Tek Yönlü Anova testi ve post hoc testi olarak Tukey testi kullanılmıştır.

Tablo 2. Örgütsel Sessizlik Ölçeği için 5 liLikert Ölçek Aralıkları

\begin{tabular}{|c|c|c|}
\hline Ağırlık & Seçenek & Sınırlar \\
\hline 1 & Kesinlikle katılmam & $1,00-1,80$ \\
\hline 2 & Katılmam & $1,81-2,60$ \\
\hline 3 & Kararsızım & $2,61-3,40$ \\
\hline 4 & Katılırım & $3,41-4,20$ \\
\hline 5 & Kesinlikle katılırım & $4,21-5,00$ \\
\hline
\end{tabular}

Araştırmaya katılan kamu çalışanlarının örgütsel sessizlik davranışlarını belirlemek için kullanılan ankette 5'li likert tipi ölçek kullanılmış olup elde edilen ortalama değerlerin yorumlanmasında kullanılacak ölçek aralıkları yukarıdaki Tablo2'de verilmiştir.

Tablo 3. Karara Katılma ve İş Özerkliği Ölçeği için 5 liLikert Ölçek Aralıkları

\begin{tabular}{|c|c|c|}
\hline A ğırlık & Seçenek & Sınırlar \\
\hline 1 & Kesinlikle katılmıyorum & $1,00-1,80$ \\
\hline 2 & Katılmıyorum & $1,81-2,60$ \\
\hline 3 & Kararsızım & $2,61-3,40$ \\
\hline 4 & Katıliyorum & $3,41-4,20$ \\
\hline 5 & Kesinlikle katılıyorum & $4,21-5,00$ \\
\hline
\end{tabular}

Araştırmaya katılan kamu çalışanlarının karara katılma ve iş özerkliği düzeylerini belirlemek için kullanılan ankette 5'li likert tipi ölçek kullanılmış olup, elde edilen ortalama değerlerin yorumlanmasında kullanılacak ölçek aralıkları Tablo3'de verilmiştir.

Tablo 4. Örgütsel Sessizlik Ölçeği ile Karara Katılma ve İş Özerkliği Ölçeği İçin Bu Çalışmada Elde Edilen Cronbach $\alpha$ İç Tutarlılık Değerleri

\begin{tabular}{|c|c|c|}
\hline & Cronbach's Alpha & N of Items \\
\hline Örgütsel Sessizlik Genel & 0,808 & 15 \\
\hline Razı Olma Sessizliği & 0,735 & 5 \\
\hline Savunma Sessizliği & 0,928 & 5 \\
\hline Prososyal Sessizlik & 0,667 & 5 \\
\hline Kararlara Katılma & 0,916 & 6 \\
\hline İs̆ Özerkliği & 0,815 & 9 \\
\hline
\end{tabular}

Bu araştırmada kullanılan 15 maddeden oluşan Örgütsel Sessizlik ölçeğinin Cronbach $\alpha$ iç tutarlılık değeri 0,808 olarak belirlenmiştir. 6 maddeden oluşan Kararlara Katılma ölçeğinde Cronbach $\alpha$ iç tutarlılık değeri 0,916 olarak ve 9 maddeden oluşan İs Özerkliği ölçeğinin Cronbach $\alpha$ iç tutarlılık değeri 0,815 olarak belirlenmiştir. Ölçeklerden elde edilen değerler güvenirliğin yeterli düzeyde olduğunu göstermektedir.

\subsection{Araştırmanın Bulguları}

Anketler aracıllı̆̆ ile toplanan verilerin analiz edilmesi sonucunda muhtelif bulgular elde edilmiştir. Söz konusu bulgular anket formundaki sıralaması da dikkate alınarak ayrı ayrı analiz edilmiştir. Bu kapsamda öncelikle katılımcıların demografik özelliklerine göre elde edilen bulgulara yer verilmiştir. 
Tablo 5. Kamu Çalışanlarının Demografik Bilgilerine Göre Dağılımlar

\begin{tabular}{|c|c|c|c|}
\hline Demografik Özellikler & Değişkenler & $\mathrm{f}$ & $\%$ \\
\hline \multirow{3}{*}{ Yaş } & $20-21$ & 1 & 0,6 \\
\hline & $22-23$ & 2 & 1,2 \\
\hline & 24 ve üzeri & 169 & 98,3 \\
\hline \multirow{2}{*}{ Cinsiyet } & Kadın & 78 & 45,3 \\
\hline & Erkek & 94 & 54,7 \\
\hline \multirow{4}{*}{ Kurumdaki hizmet süresi } & $0-5$ y1l & 13 & 7,6 \\
\hline & $6-10$ y1l & 22 & 12,8 \\
\hline & $11-15$ y1l & 40 & 23,3 \\
\hline & 16 yıl ve üzeri & 97 & 56,4 \\
\hline \multirow{4}{*}{$\begin{array}{l}\text { Boş zamanlarınızda ne } \\
\text { yapmayı tercih edersiniz? }\end{array}$} & Kitap okurum & 70 & 40,7 \\
\hline & Sinemaya giderim & 32 & 18,6 \\
\hline & Tarihi yerleri gezerim & 50 & 29,1 \\
\hline & Eğlence mekânlarına giderim & 20 & 11,6 \\
\hline \multirow{4}{*}{ Eğitim durumu } & Ortaokul & 5 & 2,9 \\
\hline & Lise & 25 & 14,5 \\
\hline & Lisans & 119 & 69,2 \\
\hline & Lisansüstü & 23 & 13,4 \\
\hline \multirow{4}{*}{$\begin{array}{l}\text { Günlük hayatta kendinizi nasıl } \\
\text { tanımlarsınız? }\end{array}$} & Sessiz sakin & 55 & 32,0 \\
\hline & Sosyal, dişa dönük & 82 & 47,7 \\
\hline & Hiperaktif (hareketli) & 19 & 11,0 \\
\hline & Sinirli ve çabuk parlayan & 16 & 9,3 \\
\hline \multirow{3}{*}{ Kadro } & Sözleşmeli & 9 & 5,2 \\
\hline & Memur / Uzman & 146 & 84,9 \\
\hline & Müdür-Üst düzey yönetici & 17 & 9,9 \\
\hline
\end{tabular}

Araştırmaya katılan örneklem grubunun demografik bilgilerinin verildiği Tablo 5'e göre araştırmaya katılan kamu çalışanlarının \%98,3'ünün 24 ve üzeri yaşta olduğu görülmektedir. Diğer yaş grupları çok az olduğundan yaş değişkeni ile ilgili gruplar arası anlamlı fark analizleri yapılmayacaktır. Çalışanların \%45,3'ü kadın, \%54,7'si erkektir. Kamudaki hizmet sürelerine bakıldığında \%56,4'ünün 16 yıl ve üzeri, \%11-15 yıl arası hizmet yaptıkları görülmektedir. Katılımcıların boş zamanlarında ne yapmayı tercih ettiklerine bakıldığında \%40,7'sinin kitap okumayı, \%29,1'inin tarihi yerleri gezmeyi tercih ettikleri görülmektedir. Çalışanların eğitim durumlarında en yüksek grubu \%69,2 ile lisans mezunları oluşturmaktadır. Araştırmaya katılanların günlük hayatta kendilerini nasıl tanımladıkları sorusunda \%47,7'lik grup sosyal ve dışa dönük olduklarını, \%32,0’lik grup ise sessiz ve sakin olduklarını beyan etmişlerdir. Katılımcıların \%84,9'unun memur veya uzman olarak çalıştıkları, \%9,9'unun müdür veya üst düzey yönetimi olarak çalıştığını görüyoruz.

Tablo 6. Karara Katılma ve İş Özerkliği Ölçeği Ortalama Puan ve Standart Sapma Değerleri

\begin{tabular}{|c|c|c|c|}
\hline Ölçek Ad 1 & $\mathrm{~N}$ & ORT & SS \\
\hline Karara Katılma & 172 & 3,92 & 0,81 \\
\hline İş Özerkliği & 172 & 3,28 & 0,72 \\
\hline
\end{tabular}

Araştırmaya katılan kamu çalışanlarının karara katılma ve iş özerkliği ölçeğine verdikleri cevaplara göre elde edilen ortalama puanlar ve standart sapma değerleri Tablo 4'de verilmiştir. Kamu çalışanlarının karara katılma ortalama puanı $\mathrm{x}=3,92 \pm 0,81$ olarak elde edilmiştir. Buna göre kamu çalışanlarının kurumlarında karara katılma 
düzeylerinin yüksek düzeyde olduğunu söyleyebiliriz. İş özerkliği ortalama puanı ise $\mathrm{x}=3,28 \pm 0,72$ olarak belirlenmiş olup, kamu çalışanlarının iş özerkliği düzeylerinin orta seviyede olduğunu söyleyebiliriz.

Tablo 7. Kamu Çalışanların Örgütsel Sessizlik Boyutları - Karara Katılma Korelasyon Tablosu

\begin{tabular}{|c|c|c|c|c|c|}
\hline & Spearman'srho & Razı Olma Sessizliği & $\begin{array}{c}\text { Savunma } \\
\text { Sessizliği }\end{array}$ & $\begin{array}{c}\text { Prososyal } \\
\text { Sessizlik }\end{array}$ & Örgütsel Sessizlik \\
\hline \multirow{3}{*}{ Karara Katılma } & CorrelationCoefficient & $0,220^{* *}$ & $0,300^{* * *}$ & $-0,078$ & $0,236^{* *}$ \\
\cline { 2 - 6 } & Sig. (2-tailed) & 0,004 & 0,000 & 0,309 & 0,002 \\
\cline { 2 - 6 } & \multicolumn{6}{|c|}{ N } & 172 & 172 & 172 & 172 \\
\hline
\end{tabular}

Araştırmaya katılan kamu çalışanlarının örgütsel sessizlik davranışları ile karara katılma düzeyleri arasındaki ilişkiyi belirlemek için yapılan korelasyon analizinde Spearman korelasyon katsayısına bakılmış ve sonuçlar Tablo 7'de verilmiştir. Buna gore kamu çalışanlarının örgütsel sessizlik düzeyi ile karara katılma düzeyleri arasında pozitif yönde zayıf bir ilişki bulunduğu görülmektedir $(r=0,236 \mathrm{p}=0,002)$. Aynı şekilde razı olma sessizliği ile karara katılma düzeyleri arasında $(\mathrm{r}=0,220 \mathrm{p}=0,004)$ ve savunma sessizliği ile karara katılma düzeyleri arasında da $(r=0,300 \mathrm{p}=0,000)$ pozitif yönde zayıf bir ilişki bulunduğu görülmektedir.

Tablo 8. Kamu Çalışanlarının Örgütsel Sessizlik Boyutları - İş Özerkliği Korelasyon Tablosu

\begin{tabular}{|c|c|c|c|c|c|}
\hline \multicolumn{2}{|c|}{} & Razı Olma Sessizliği & Savunma Sessizliği & Prososyal Sessizlik & Örgütsel Sessizlik \\
\hline \multirow{3}{*}{ İş Özerkliği } & PearsonCorrelation & $0,285^{* *}$ & $0,210^{* *}$ & $-0,034$ & $0,236^{* *}$ \\
\cline { 2 - 6 } & Sig. (2-tailed) & 0,000 & 0,006 & 0,662 & 0,002 \\
\cline { 2 - 6 } & N & 172 & 172 & 172 & 172 \\
\hline \multicolumn{7}{|c|}{ * Korelasyon çift yönlü 0,01 düzeyinde anlamlıdır. } \\
\hline
\end{tabular}

Araştırmaya katılan Araştırmaya katılan kamu çalışanlarının örgütsel sessizlik davranışları ile iş özerkliği düzeyleri arasındaki ilişkiyi belirlemek için yapılan korelasyon analizinde Pearson korelasyon katsayısına bakılmış ve sonuçlar Tablo $8^{\prime}$ de verilmiştir. Buna göre kamu çalışanlarının örgütsel sessizlik düzeyi ile iş özerkliği düzeyleri arasında pozitif yönde zayıf bir ilişki bulunduğu görülmektedir $(r=0,236 \mathrm{p}=0,002)$. Aynı şekilde razı olma sessizliği ile iş özerkliği düzeyleri arasında $(r=0,285 \mathrm{p}=0,000)$ ve savunma sessizliği ile iş özerkliği düzeyleri arasında da $(r=0,210 \mathrm{p}=0,006)$ pozitif yönde zayıf bir ilişki bulunduğu görülmektedir.

Tablo 9. Kamu Çalışanlarının Örgütsel Sessizlik Davranışlarını Cinsiyet Değişkenine Göre Karşılaştıran T Testi Sonuçları

\begin{tabular}{|c|c|c|c|c|c|c|}
\hline Sessizlik Türü & Cinsiyet & $\mathrm{N}$ & ORT & SS & $\mathrm{t}$ & $\mathrm{P}$ \\
\hline \multirow{2}{*}{ Razı Olma Sessizliği } & Kadın & 78 & 3,14 & 0,78 & \multirow{2}{*}{$-0,265$} & \multirow{2}{*}{0,792} \\
\hline & Erkek & 94 & 3,17 & 0,75 & & \\
\hline \multirow{2}{*}{ Savunma Sessizliği } & Kadın & 78 & 3,47 & 1,05 & \multirow{2}{*}{$-1,607$} & \multirow{2}{*}{0,110} \\
\hline & Erkek & 94 & 3,71 & 0,92 & & \\
\hline \multirow{2}{*}{ Prososyal Sessizlik } & Kadın & 78 & 3,60 & 0,67 & \multirow{2}{*}{0,060} & \multirow{2}{*}{0,952} \\
\hline & Erkek & 94 & 3,59 & 0,72 & & \\
\hline \multirow{2}{*}{ Örgütsel Sessizlik } & Kadın & 78 & 3,40 & 0,55 & \multirow{2}{*}{$-1,021$} & \multirow{2}{*}{0,309} \\
\hline & Erkek & 94 & 3,49 & 0,58 & & \\
\hline
\end{tabular}

Araştırmaya katılan kamu çalışanlarının örgütsel sessizlik davranışlarını cinsiyet değişkenine göre değerlendirdiğimiz T testi analiz sonuçları Tablo 9'da verilmiştir. Yapılan T testi sonuçlarında örgütsel sessizlik davranışlarında kadın ve erkek çalışanlar arasında anlamlı bir fark bulunmamıştır. 
Tablo 10. Kamu Çalışanlarının Örgütsel Sessizlik Davranışlarını Hizmet Süresi Değişkenine Göre Karşılaştıran Tek Yönlü Anova Testi Sonuçları

\begin{tabular}{|c|c|c|c|c|c|c|c|}
\hline Sessizlik Türü & Hizmet Süresi & $\mathrm{N}$ & ORT & SS & $\mathrm{F}$ & $\mathrm{P}$ & FARK \\
\hline \multirow{4}{*}{$\begin{array}{l}\text { Razı Olma } \\
\text { Sessizliği }\end{array}$} & $0-5$ y1l & 13 & 2,60 & 0,93 & \multirow{4}{*}{2,756} & \multirow{4}{*}{$0,044 * *$} & \multirow{4}{*}{$\begin{array}{l}1-3 \\
1-4\end{array}$} \\
\hline & $6-10$ y1l & 22 & 3,22 & 0,63 & & & \\
\hline & 11-15 y1l & 40 & 3,27 & 0,79 & & & \\
\hline & 16 yıl ve üzeri & 97 & 3,18 & 0,73 & & & \\
\hline \multirow{4}{*}{$\begin{array}{l}\text { Savunma } \\
\text { Sessizliği }\end{array}$} & $0-5$ y1l & 13 & 3,26 & 0,98 & \multirow{4}{*}{1,152} & \multirow{4}{*}{0,330} & \\
\hline & $6-10$ y1l & 22 & 3,68 & 0,86 & & & \\
\hline & $11-15$ y1l & 40 & 3,79 & 0,87 & & & \\
\hline & 16 yıl ve üzeri & 97 & 3,55 & 1,05 & & & \\
\hline \multirow{4}{*}{$\begin{array}{c}\text { Prososyal } \\
\text { Sessizlik }\end{array}$} & $0-5$ y1l & 13 & 3,45 & 0,74 & \multirow{4}{*}{0,268} & \multirow{4}{*}{0,849} & \\
\hline & $6-10$ y1l & 22 & 3,56 & 0,62 & & & \\
\hline & $11-15 \mathrm{y} 1 \mathrm{l}$ & 40 & 3,64 & 0,80 & & & \\
\hline & 16 yıl ve üzeri & 97 & 3,61 & 0,66 & & & \\
\hline \multirow{4}{*}{$\begin{array}{l}\text { Örgütsel } \\
\text { Sessizlik }\end{array}$} & $0-5$ y1l & 13 & 3,10 & 0,64 & \multirow{4}{*}{2,227} & \multirow{4}{*}{0,087} & \\
\hline & $6-10$ y1l & 22 & 3,49 & 0,39 & & & \\
\hline & $11-15$ y1l & 40 & 3,56 & 0,59 & & & \\
\hline & 16 yıl ve üzeri & 97 & 3,44 & 0,57 & & & \\
\hline
\end{tabular}

Araştırmaya katılan kamu çalışanlarının örgütsel sessizlik davranışlarını hizmet süresi değişkenine göre değerlendirdiğimiz Tek Yönlü Anova testi analiz sonuçları Tablo 10'da verilmiştir. Yapılan Tek Yönlü Anova testi sonuçlarında razı olma sessizliği boyutu için hizmet süresi 11-15 yıl olan çalışanların $(x=3,27 \pm 0,79)$ ve 16 yıl ve üzeri olan çalışanların $(x=3,18 \pm 0,73)$ düzeylerinin hizmet süresi $0-5$ yıl arası olanlara göre $(x=2,60 \pm 0,93)$ anlamlı bir şekilde daha yüksek olduğu görülmüştür $(\mathrm{p}<0,05)$.

Tablo 11. Kamu Çalışanlarının Örgütsel Sessizlik Davranışlarını Boş Zaman Değerlendirme Değişkenine Göre Karşılaştıran Tek Yönlü Anova Testi Sonuçları

\begin{tabular}{|c|c|c|c|c|c|c|}
\hline Sessizlik Türü & Boş Zamanları Değerlendirme & $\mathrm{N}$ & ORT & SS & $\mathrm{F}$ & $\mathrm{P}$ \\
\hline \multirow{4}{*}{$\begin{array}{c}\text { Razı Olma } \\
\text { Sessizliği }\end{array}$} & Kitap okurum & 70 & 3,21 & 0,73 & \multirow{4}{*}{0,262} & \multirow{4}{*}{0,853} \\
\hline & Sinemaya giderim & 32 & 3,13 & 0,66 & & \\
\hline & Tarihi yerleri gezerim & 50 & 3,10 & 0,84 & & \\
\hline & Eğlence mekânlarına giderim & 20 & 3,21 & 0,82 & & \\
\hline \multirow{4}{*}{ Savunma Sessizliği } & Kitap okurum & 70 & 3,66 & 1,02 & \multirow{4}{*}{0,382} & \multirow{4}{*}{0,766} \\
\hline & Sinemaya giderim & 32 & 3,58 & 0,91 & & \\
\hline & Tarihi yerleri gezerim & 50 & 3,61 & 0,97 & & \\
\hline & Eğlence mekânlarına giderim & 20 & 3,39 & 1,06 & & \\
\hline \multirow{4}{*}{ Prososyal Sessizlik } & Kitap okurum & 70 & 3,61 & 0,67 & \multirow{4}{*}{0,435} & \multirow{4}{*}{0,728} \\
\hline & Sinemaya giderim & 32 & 3,52 & 0,78 & & \\
\hline & Tarihi yerleri gezerim & 50 & 3,58 & 0,73 & & \\
\hline & Eğlence mekânlarına giderim & 20 & 3,74 & 0,54 & & \\
\hline \multirow{4}{*}{ Örgütsel Sessizlik } & Kitap okurum & 70 & 3,49 & 0,53 & \multirow{4}{*}{0,195} & \multirow{4}{*}{0,900} \\
\hline & Sinemaya giderim & 32 & 3,41 & 0,59 & & \\
\hline & Tarihi yerleri gezerim & 50 & 3,43 & 0,60 & & \\
\hline & Eğlence mekânlarına giderim & 20 & 3,45 & 0,60 & & \\
\hline \multicolumn{3}{|c|}{ ** $\mathrm{P}<0,05$ düzeyinde anlamlı fark ifade etmektedir. } & & & & \\
\hline
\end{tabular}

Araştırmaya katılan kamu çalışanlarının örgütsel sessizlik davranışlarını boş zaman değerlendirme değişkenine göre değerlendirdiğimiz Tek Yönlü Anova testi analiz sonuçları Tablo 11'de verilmiştir. Yapılan Tek Yönlü Anova testi sonuçlarında örgütsel sessizlik davranışlarında boş zaman değerlendirme grupları arasında anlamlı bir fark bulunmamıştır. 
Tablo 12. Kamu Çalışanlarının Örgütsel Sessizlik Davranışlarını Eğitim Durumu Değişkenine Göre Karşılaştıran Tek Yönlü Anova Testi Sonuçları

\begin{tabular}{|c|c|c|c|c|c|c|}
\hline & Eğitim Durumu & $\mathrm{N}$ & ORT & SS & $\mathrm{F}$ & $\mathrm{P}$ \\
\hline \multirow{4}{*}{ Razı Olma Sessizliği } & Ortaokul & 5 & 3,60 & 0,24 & \multirow{4}{*}{0,912} & \multirow{4}{*}{0,436} \\
\hline & Lise & 25 & 3,26 & 0,73 & & \\
\hline & Lisans & 119 & 3,15 & 0,78 & & \\
\hline & Lisansüstü & 23 & 3,03 & 0,72 & & \\
\hline \multirow{4}{*}{ Savunma Sessizliği } & Ortaokul & 5 & 3,64 & 0,61 & \multirow{4}{*}{0,041} & \multirow{4}{*}{0,989} \\
\hline & Lise & 25 & 3,65 & 0,84 & & \\
\hline & Lisans & 119 & 3,58 & 1,03 & & \\
\hline & Lisansüstü & 23 & 3,63 & 1,02 & & \\
\hline \multirow{4}{*}{ Prososyal Sessizlik } & Ortaokul & 5 & 3,92 & 0,95 & \multirow{4}{*}{0,382} & \multirow{4}{*}{0,766} \\
\hline & Lise & 25 & 3,57 & 0,67 & & \\
\hline & Lisans & 119 & 3,59 & 0,68 & & \\
\hline & Lisansüstü & 23 & 3,57 & 0,74 & & \\
\hline \multirow{4}{*}{ Örgütsel Sessizlik } & Ortaokul & 5 & 3,72 & 0,43 & \multirow{4}{*}{0,464} & \multirow{4}{*}{0,708} \\
\hline & Lise & 25 & 3,49 & 0,52 & & \\
\hline & Lisans & 119 & 3,44 & 0,59 & & \\
\hline & Lisansüstü & 23 & 3,41 & 0,53 & & \\
\hline
\end{tabular}

Araştırmaya katılan kamu çalışanlarının örgütsel sessizlik davranışlarını eğitim durumu değişkenine göre değerlendirdiğimiz Tek Yönlü Anova testi analiz sonuçları Tablo 12'de verilmiştir. Yapılan Tek Yönlü Anova testi sonuçlarında örgütsel sessizlik davranışlarında eğitim durumu grupları arasında anlamlı bir fark bulunmamıştır.

Tablo 13. Kamu Çalışanlarının Örgütsel Sessizlik Davranışlarını Kendini Tanımlama Değişkenine Göre Karşılaştıran Tek Yönlü Anova Testi Sonuçları

\begin{tabular}{|c|c|c|c|c|c|c|c|}
\hline Sessizlik Türü & Kendini Tanımlama & $\mathrm{N}$ & ORT & SS & $\mathrm{F}$ & $\mathrm{P}$ & FARK \\
\hline \multirow{4}{*}{$\begin{array}{c}\text { Razı Olma } \\
\text { Sessizliği }\end{array}$} & Sessiz sakin & 55 & 3,41 & 0,64 & \multirow{4}{*}{5,163} & \multirow{4}{*}{$0,002 * *$} & \multirow{4}{*}{$1-2$} \\
\hline & Sosyal, dişa dönük & 82 & 2,97 & 0,71 & & & \\
\hline & Hiperaktif (hareketli) & 19 & 3,43 & 0,88 & & & \\
\hline & Sinirli ve çabuk parlayan & 16 & 2,99 & 0,96 & & & \\
\hline \multirow{4}{*}{$\begin{array}{l}\text { Savunma } \\
\text { Sessizliği }\end{array}$} & Sessiz sakin & 55 & 3,64 & 1,01 & \multirow{4}{*}{0,050} & \multirow{4}{*}{0,985} & \\
\hline & Sosyal, dişa dönük & 82 & 3,58 & 0,92 & & & \\
\hline & Hiperaktif (hareketli) & 19 & 3,60 & 1,31 & & & \\
\hline & Sinirli ve çabuk parlayan & 16 & 3,56 & 0,93 & & & \\
\hline \multirow{4}{*}{$\begin{array}{l}\text { Prososyal } \\
\text { Sessizlik }\end{array}$} & Sessiz sakin & 55 & 3,48 & 0,75 & \multirow{4}{*}{1,081} & \multirow{4}{*}{0,359} & \\
\hline & Sosyal, dişa dönük & 82 & 3,65 & 0,64 & & & \\
\hline & Hiperaktif (hareketli) & 19 & 3,76 & 0,61 & & & \\
\hline & Sinirli ve çabuk parlayan & 16 & 3,51 & 0,84 & & & \\
\hline \multirow{4}{*}{$\begin{array}{l}\text { Örgütsel } \\
\text { Sessizlik }\end{array}$} & Sessiz sakin & 55 & 3,51 & 0,54 & \multirow{4}{*}{1,014} & \multirow{4}{*}{0,388} & \\
\hline & Sosyal, dişa dönük & 82 & 3,40 & 0,52 & & & \\
\hline & Hiperaktif (hareketli) & 19 & 3,60 & 0,72 & & & \\
\hline & Sinirli ve çabuk parlayan & 16 & 3,35 & 0,69 & & & \\
\hline
\end{tabular}

Araştırmaya katılan kamu çalışanlarının örgütsel sessizlik davranışlarını kendini tanımlama değişkenine göre değerlendirdiğimiz Tek Yönlü Anova testi analiz sonuçları Tablo 13'de verilmiştir. Yapılan Tek Yönlü Anova testi sonuçlarında razı olma sessizliği boyutu için sessiz ve sakin olan çalışanların düzeylerinin $(x=3,41 \pm 0,64)$ sosyal ve dışa dönük olanlara göre $(x=2,97 \pm 0,71)$ anlamlı bir şekilde daha yüksek olduğu görülmüştür $(\mathrm{p}<0,05)$. 
GÖZÜM, Perihan - Covid-19 Salgını Döneminde Kamu Çalışanlarının Örgütsel Sessizlik Davranışlarının Kararlara Katılma ve İş Özerkliği Uygulamaları Üzerine Etkisi

Tablo 14. Kamu Çalışanlarının Örgütsel Sessizlik Davranışlarını Kadro Değişkenine Göre Karşılaştıran Anova Testi

\begin{tabular}{|c|c|c|c|c|c|c|}
\hline Sessizlik Türü & Kadronuz & $\mathrm{N}$ & ORT & SS & $\mathrm{F}$ & $\mathrm{P}$ \\
\hline \multirow{3}{*}{$\begin{array}{c}\text { Razı Olma } \\
\text { Sessizliği }\end{array}$} & Sözleşmeli & 9 & 3,27 & 0,77 & \multirow{3}{*}{0,466} & \multirow{3}{*}{0,628} \\
\hline & Memur / Uzman & 146 & 3,14 & 0,77 & & \\
\hline & Müdür-Üst düzey yönetici & 17 & 3,31 & 0,67 & & \\
\hline \multirow{3}{*}{$\begin{array}{l}\text { Savunma } \\
\text { Sessizliği }\end{array}$} & Sözleşmeli & 9 & 3,60 & 0,57 & \multirow{3}{*}{2,429} & \multirow{3}{*}{0,091} \\
\hline & Memur / Uzman & 146 & 3,54 & 1,00 & & \\
\hline & Müdür-Üst düzey yönetici & 17 & 4,09 & 0,95 & & \\
\hline \multirow{3}{*}{$\begin{array}{l}\text { Prososyal } \\
\text { Sessizlik }\end{array}$} & Sözleşmeli & 9 & 3,98 & 0,76 & \multirow{3}{*}{2,709} & \multirow{3}{*}{0,069} \\
\hline & Memur / Uzman & 146 & 3,55 & 0,68 & & \\
\hline & Müdür-Üst düzey yönetici & 17 & 3,82 & 0,73 & & \\
\hline \multirow{3}{*}{ Örgütsel Sessizlik } & Sözleşmeli & 9 & 3,62 & 0,46 & \multirow{3}{*}{3,074} & \multirow{3}{*}{0,049} \\
\hline & Memur / Uzman & 146 & 3,41 & 0,57 & & \\
\hline & Müdür-Üst düzey yönetici & 17 & 3,74 & 0,49 & & \\
\hline
\end{tabular}

Araştırmaya katılan kamu çalışanlarının örgütsel sessizlik davranışlarını kadro değişkenine gore değerlendirdiğimiz Tek Yönlü Anova testi analiz sonuçları Tablo 14'de verilmiştir. Yapılan Tek Yönlü Anova testi sonuçlarında örgütsel sessizlik davranışlarında kadro grupları arasında anlamlı bir fark bulunmamıştır.

Tablo 15. Kamu Personelinin Karara Katılma Düzeylerinin Cinsiyete Göre Karşılaştırılmsı (Mann Whitney U Testi)

\begin{tabular}{|c|c|c|c|c|c|c|}
\hline & Cinsiyet & $\mathrm{N}$ & Sira Ortalaması & Sira Toplamı & Mann-Whitney U & $\mathrm{P}$ \\
\hline \multirow{2}{*}{ Karara Katılma } & Kadın & 78 & 89,69 & 6995,50 & \multirow{2}{*}{3417,50} & \multirow{2}{*}{0,432} \\
\hline & Erkek & 94 & 83,86 & 7882,50 & & \\
\hline
\end{tabular}

Araştırmaya katılan kamu çalışanlarının karara katılma düzeylerini cinsiyet değişkenine göre değerlendirdiğimiz Mann Whitney U testi analiz sonuçları Tablo 15'de verilmiştir. Yapılan analiz sonuçlarında kamu çalışanlarının karara katılma düzeylerinde kadın ve erkek çalışanlar arasında anlamlı bir fark bulunmamıştır.

Tablo 16. Kamu Çalışanlarının Karara Katılma Düzeylerinin Demografik Değişkenlere Göre Karşılaştırıldığı Kruskal Wallis Testi Sonuçları

\begin{tabular}{|c|c|c|c|c|c|c|}
\hline \multicolumn{2}{|r|}{ Değişkenler } & $\mathrm{N}$ & Sira Ortalaması & Ki Kare & $\mathrm{P}$ & FARK \\
\hline \multirow{4}{*}{ Hizmet Süresi } & $0-5 \mathrm{y} 1 \mathrm{l}$ & 13 & 64,62 & \multirow{4}{*}{3,138} & \multirow{4}{*}{0,371} & \\
\hline & $6-10$ y1l & 22 & 88,48 & & & \\
\hline & $11-15$ y1l & 40 & 84,94 & & & \\
\hline & 16 yıl ve üzeri & 97 & 89,63 & & & \\
\hline \multirow{4}{*}{$\begin{array}{c}\text { Boş Zaman } \\
\text { Değerlendirme }\end{array}$} & Kitap okurum & 70 & 85,72 & \multirow{4}{*}{4,438} & \multirow{4}{*}{0,218} & \\
\hline & Sinemaya giderim & 32 & 98,33 & & & \\
\hline & Tarihi yerleri gezerim & 50 & 86,88 & & & \\
\hline & Eğlence mekânlarına giderim & 20 & 69,35 & & & \\
\hline \multirow{4}{*}{ Eğitim } & Ortaokul & 5 & 67,30 & \multirow{4}{*}{8,670} & \multirow{4}{*}{$0,034 * *$} & \multirow{4}{*}{$\begin{array}{l}1-3 \\
2-3\end{array}$} \\
\hline & Lise & 25 & 63,46 & & & \\
\hline & Lisans & 119 & 92,90 & & & \\
\hline & Lisansüstü & 23 & 82,61 & & & \\
\hline \multirow{4}{*}{$\begin{array}{c}\text { Kendini } \\
\text { Tanımlama }\end{array}$} & Sessiz sakin & 55 & 93,17 & \multirow{4}{*}{3,778} & \multirow{4}{*}{0,286} & \\
\hline & Sosyal, dişa dönük & 82 & 84,57 & & & \\
\hline & Hiperaktif (hareketli) & 19 & 91,34 & & & \\
\hline & Sinirli ve çabuk parlayan & 16 & 67,69 & & & \\
\hline \multirow{3}{*}{ Kadronuz } & Sözleşmeli & 9 & 67,33 & \multirow{3}{*}{1,776} & \multirow{3}{*}{0,411} & \\
\hline & Memur / Uzman & 146 & 86,86 & & & \\
\hline & Müdür-Üst düzey yönetici & 17 & 93,53 & & & \\
\hline & $* * \mathrm{P}<0,05$ düze & nlan & $\mathrm{k}$ ifade etmekte & & & \\
\hline
\end{tabular}


Araştırmaya katılan kamu çalışanlarının karara katılma düzeylerini hizmet süresi, boş zaman değerlendirme, eğitim durumu, kendini tanımlama ve kadro değişkenine göre değerlendirdiğimiz Kruskal Wallis testi analiz sonuçları Tablo 16'da verilmiştir. Yapılan analiz sonuçlarında eğitim durumu değişkeni için lisans mezunu çalışanların karara katılma düzeylerinin lise mezunu olan ve ortaokul mezunu olan çalışanlara göre anlamlı bir şekilde daha yüksek olduğu görülmüştür $(\mathrm{p}<0,05)$.

Tablo 17. Kamu Çalışanlarının İş Özerkliği Düzeylerinin Cinsiyet Değiş̧kenine Göre Karşılaştırıldığı T Testi Sonuçları

\begin{tabular}{|c|c|c|c|c|c|c|}
\hline & Cinsiyet & $\mathrm{N}$ & ORT & SS & $\mathrm{t}$ & $\mathrm{P}$ \\
\hline \multirow{2}{*}{ İş Özerkliği } & Kadın & 78 & 3,16 & 0,71 & \multirow{2}{*}{$-2,096$} & \multirow{2}{*}{$0,038 * *$} \\
\cline { 2 - 6 } & Erkek & 94 & 3,39 & 0,71 & \\
\hline \multicolumn{7}{|c|}{$* * \mathrm{P}<0,05$ düzeyinde anlamlı fark ifade etmektedir. } \\
\hline
\end{tabular}

Araştırmaya katılan kamu çalışanlarının iş özerkliği düzeylerini cinsiyet değişkenine göre değerlendirdiğimiz T testi analiz sonuçları Tablo 17 'de verilmiştir. Yapılan $\mathrm{T}$ testi sonuçlarında erkek çalışanların iş özerkliği düzeylerinin $(x=3,39 \pm 0,71)$ kadın çalışanlara göre $(x=3,16 \pm 0,71)$ anlamlı bir şekilde daha yüksek olduğu görülmüştür $(\mathrm{p}<0,05)$.

Tablo 18. Kamu Çalışanlarının İş Özerkliği Düzeylerinin Demografik Değişkenlere Göre Karşılaştırıldığı Tek Yönlü Anova Testi Sonuçları

\begin{tabular}{|c|c|c|c|c|c|c|}
\hline \multicolumn{2}{|c|}{ Değişkenler } & $\mathrm{N}$ & ORT & SS & $\mathrm{F}$ & $\mathrm{P}$ \\
\hline \multirow{4}{*}{ Hizmet Süresi } & $0-5$ y1l & 13 & 2,92 & 0,86 & \multirow{4}{*}{2,592} & \multirow{4}{*}{0,054} \\
\hline & $6-10$ y1l & 22 & 3,39 & 0,54 & & \\
\hline & $11-15$ y1l & 40 & 3,48 & 0,86 & & \\
\hline & 16 y1l ve üzeri & 97 & 3,23 & 0,65 & & \\
\hline \multirow{4}{*}{$\begin{array}{c}\text { Boş Zaman } \\
\text { Değerlendirme }\end{array}$} & Kitap okurum & 70 & 3,31 & 0,70 & \multirow{4}{*}{0,508} & \multirow{4}{*}{0,677} \\
\hline & Sinemaya giderim & 32 & 3,36 & 0,67 & & \\
\hline & Tarihi yerleri gezerim & 50 & 3,18 & 0,74 & & \\
\hline & Eğlence mekânlarına giderim & 20 & 3,33 & 0,83 & & \\
\hline \multirow{4}{*}{ Eğitim } & Ortaokul & 5 & 3,38 & 0,67 & \multirow{4}{*}{0,435} & \multirow{4}{*}{0,728} \\
\hline & Lise & 25 & 3,25 & 0,62 & & \\
\hline & Lisans & 119 & 3,26 & 0,76 & & \\
\hline & Lisansüstü & 23 & 3,44 & 0,64 & & \\
\hline \multirow{4}{*}{$\begin{array}{c}\text { Kendini } \\
\text { Tanımlama }\end{array}$} & Sessiz sakin & 55 & 3,35 & 0,58 & \multirow{4}{*}{2,136} & \multirow{4}{*}{0,098} \\
\hline & Sosyal, dişa dönük & 82 & 3,15 & 0,68 & & \\
\hline & Hiperaktif (hareketli) & 19 & 3,50 & 0,89 & & \\
\hline & Sinirli ve çabuk parlayan & 16 & 3,48 & 0,98 & & \\
\hline \multirow{3}{*}{ Kadronuz } & Sözleşmeli & 9 & 3,40 & 0,63 & \multirow{3}{*}{0,236} & \multirow{3}{*}{0,790} \\
\hline & Memur / Uzman & 146 & 3,29 & 0,73 & & \\
\hline & Müdür-Üst düzey yönetici & 17 & 3,20 & 0,63 & & \\
\hline
\end{tabular}

Araştırmaya katılan kamu çalışanlarının iş özerkliği düzeylerini hizmet süresi, boş zaman değerlendirme, eğitim durumu, kendini tanımlama ve kadro değişkenine göre değerlendirdiğimiz Tek Yönlü Anova testi analiz sonuçları Tablo 18 'de verilmiştir. Yapılan analiz sonuçlarında gruplar arasında herhangi bir anlamlı fark görülmemiştir. 


\section{SONUÇ}

Araştırmaya katılan kamu çalışanlarının \%98,3'ünün 24 ve üzeri yaşta olduğu görülmektedir. Diğer yaş grupları çok az olduğundan yaş değişkeni ile ilgili gruplar arası anlamlı fark analizleri yapılmayacaktır. Çalışanların \%45,3'ü kadın, \%54,7'si erkektir. Kamudaki hizmet sürelerine bakıldığında \%56,4'ünün 16 yıl ve üzeri, \%1115 yıl arası hizmet yaptıkları görülmektedir. Katılımcıların boş zamanlarında ne yapmayı tercih ettiklerine bakıldığında \%40,7'sinin kitap okumayı, \%29,1'inin tarihi yerleri gezmeyi tercih ettikleri görülmektedir. Çalışanların eğitim durumlarında en yüksek grubu \%69,2 ile lisans mezunları oluşturmaktadır. Araştırmaya katılanların günlük hayatta kendilerini nasıl tanımladıkları sorusunda \%47,7'lik grup sosyal ve dışa dönük olduklarını, \%32,0'lik grup ise sessiz ve sakin olduklarını beyan etmişlerdir. Katılımcıların \%84,9'unun memur veya uzman olarak çalıştıkları, \%9,9'unun müdür veya üst düzey yönetimi olarak çalıştığını görüyoruz.

Araştırmaya katılan kamu çalışanlarının karara katılma ve iş özerkliği ölçeğine verdikleri cevaplara göre elde edilen ortalama puanlar ve standart sapma değerlerine göre kamu çalışanlarının kurumlarında karara katılma düzeylerinin yüksek düzeyde olduğunu söyleyebiliriz. Kamu çalışanlarının iş özerkliği düzeylerinin orta seviyede olduğunu söyleyebiliriz. Örgütsel sessizlik düzeyi ile karara katılma düzeyleri arasında pozitif yönde zayıf bir ilişki bulunduğu görülmektedir. Aynı şekilde razı olma sessizliği ile karara katılma düzeyleri arasında ve savunma sessizliği ile karara katılma düzeyleri arasında da pozitif yönde zayıf bir ilişki bulunduğu görülmektedir. Örgütsel sessizlik düzeyi ile iş özerkliği düzeyleri arasında pozitif yönde zayıf bir ilişki bulunduğu görülmektedir. Aynı şekilde razı olma sessizliği ile iş özerkliği düzeyleri arasında ve savunma sessizliği ile iş özerkliği düzeyleri arasında da pozitif yönde zayıf bir ilişki bulunduğu görülmektedir.

Örgütsel sessizlik davranışlarını cinsiyet değişkenine göre değerlendirdiğimizde örgütsel sessizlik davranışlarında kadın ve erkek çalışanlar arasında anlamlı bir fark bulunmamıştır. Örgütsel sessizlik davranışlarını hizmet süresi değişkenine göre değerlendirdiğimiz de razı olma sessizliği boyutu için hizmet süresi 11-15 yıl olan çalışanların ve 16 yıl ve üzeri olan çalışanların örgütsel sessizlik davranış düzeylerinin hizmet süresi 0-5 yıl arası olanlara göre anlamlı bir şekilde daha yüksek olduğu görülmüştür.

Örgütsel sessizlik davranışlarını boş zaman değerlendirme değişkenine göre değerlendirdiğimizde örgütsel sessizlik davranışlarında boş zaman değerlendirme grupları arasında anlamlı bir fark bulunmamıştır. Örgütsel sessizlik davranışlarını eğitim durumu değişkenine göre değerlendirdiğimiz örgütsel sessizlik davranışlarında eğitim durumu grupları arasında anlamlı bir fark bulunmamıştır. Örgütsel sessizlik davranışlarını kendini tanımlama değişkenine göre değerlendirdiğimiz de razı olma sessizliği boyutu için sessiz ve sakin olan çalışanların düzeylerinin sosyal ve dışa dönük olanlara göre anlamlı bir şekilde daha yüksek olduğu görülmüştür.

Örgütsel sessizlik davranışlarını kadro değişkenine göre değerlendirdiğimizde örgütsel sessizlik davranışlarında kadro grupları arasında anlamlı bir fark bulunmamıştır. Araştırmaya katılan kamu çalışanlarının karara katılma düzeylerini cinsiyet değişkenine göre değerlendirdiğimiz de karara katılma düzeylerinde kadın ve erkek çalışanlar arasında anlamlı bir fark bulunmamıştır. Karara katılma düzeylerini hizmet süresi, boş zaman değerlendirme, eğitim durumu, kendini tanımlama ve kadro değişkenine göre değerlendirdiğimiz de eğitim durumu değişkeni için lisans mezunu çalışanların karara katılma düzeylerinin lise mezunu olan ve ortaokul mezunu olan çalışanlara göre anlamlı bir şekilde daha yükssek olduğu görülmüştür.

Araştırmaya katılan kamu çalışanlarının iş özerkliği düzeylerini cinsiyet değişkenine göre değerlendirdiğimizde erkek çalışanların iş özerkliği düzeylerinin kadın çalışanlara göre anlamlı bir şekilde daha yüksek olduğu görülmüştür. İş özerkliği düzeylerini hizmet süresi, boş zaman değerlendirme, eğitim durumu, kendini tanımlama ve kadro değişkenine göre değerlendirdiğimiz de gruplar arasında herhangi bir anlamlı fark görülmemiştir. 


\section{KAYNAKLAR}

2020/8 sayılı Cumhurbaşkanlığı Genelgesi (29.05.2020 tarih ve 31139 - Mükerrer sayılı Resmi Gazete).

AÇIKGÖZ, Kemal (1988), “Katılmanın Kuramsal Temelleri ve Katılma Araştırmaları”, Ankara Üniversitesi Ĕ̆itim Bilimleri Dergisi, S.20(1-2), ss.21-28.

ALPARSLAN, Ali ve KAYALAR, Murat (2012), "Örgütsel Sessizlik: Sessizlik Davranışları ve Örgütsel ve Bireysel Etkileri”, Mehmet Akif Ersoy Üniversitesi Sosyal Bilimler Enstitüsü Dergisi, S.4(6), ss.136147.

ASLAN, Recep (2020), “Kovid-19 Fizyoloji ve Psikolojiyi Nasıl Etkiliyor?”, Göller Bölgesi Aylık Ekonomi ve Kültür Dergisi, S.8(88), ss.47-53.

AYDIN, Mustafa (1994), Eğitim Yönetimi, Hatipoğlu Yayınevi, Ankara.

BALAY, Refik (2000), Yönetici ve Öğretmenlerde Örgütsel Bağlılık, Nobel Yayınları, Ankara.

BAŞARAN, İbrahim Ethem (2000), Örgütsel Davranış, Feryal Matbaası, Ankara.

BATEMAN, Thomas S. ve ZEITHAML, Carl P. (1990), Management: Function and Strategy, Richard D. Irwin Inc., Boston.

BAY, Murat ve BAYRAÇ, Ahmet (2021), “Örgütsel Sessizlik”, Örgütsel Davranış Üzerine Literatürel naliz ve Ölçekler (Ed.Murat Ak), Nobel Yayınları, Ankara, ss.483-507.

BENLI, Abdurrahman ve CEREV, Gökçe (2017), "Örgütsel Sessizlik ve Tükenmişlik İlişkisi: Turizm Çalışanları Örneği”, Yönetim Bilimleri Dergisi, S.15(30), ss.411-433.

BLACKMAN, Deborah ve SADLER-SMITH, Eugene (2009), "The Silent and the Silenced in Organizational Knowing and Learning, Management Learning, S.40(5), ss.569-585.

BLENKINSOPP, John ve EDWARDS, Marissa S. (2008), “On Not Blowing the Whistle: Quiescent Silence as an Emotion Episode", Emotions, Ethics and Decision-Making (Ed. W. J. Zerbe, C. E. J. Hartel ve N. M. Ashkanasy), JAI Press, Bingley (UK), ss.181-206.

BOWEN, Frances ve BLACKMON, Kate (2003), "Spirals of Silence: the Dynamic Effects of Diversity on Organizational Voice", Journal of Management Studies, S.40(6), ss.1393-1417.

BRINK, Alisa G., EMERSON, David J. ve YANG, Ling (2016), “Job Autonomy and Counter Productive Behaviors in Chinese Accountants: the Role of Job - Related Attitudes", Journal of International Accounting Research, S.15(1), ss.115-131.

ÇAKICI, Ayşehan (2007), “Örgütlerde Sessizlik: Sessizliğin Teorik Temelleri ve Dinamikleri”, Ç.Ü. Sosyal Bilimler Enstitüsü Dergisi, S.16(1), ss.145-162.

DOĞAN, Hulusi ve CAN, Ali (2009), "Örgütlerde Mesleki Özerklik Sorunu ve Süleyman Demirel Üniversitesi Sağlık Araştırma ve Uygulama Merkezi’nde Ampirik Bir Çalışma”, Çukurova Üniversitesi Sosyal Bilimler Enstitüsü Dergisi, S.18(1), ss.133-148.

DYNE, Linn Van, ANG, Soon ve BOTERO, Isabel C. (2003), "Conceptualizing Employee Silence and Employee Voice as Multi Dimensional Constructs", Journal of Management Studies, S.40 (6), ss.13591392.

DYSVIK, Anders ve KUVAAS, Bård (2011), "Intrinsic Motivation as a Moderator on The Relationship Between Perceived Job Autonomy and Work Performance", European Journal of Work and Organizational Psychology, S.20(3), ss.367-387.

EDMONSON, Amy C. (1999), "Psychological Safety and Learning Behaviour in Work Teams, Administrative", Science Quarterly, S.44(2), ss.350-383.

EREN, Erol (2000), Örgütsel Davranış ve Yönetim Psikolojisi, Beta Yayınları, İstanbul, 6. Baskı.

GEPHART, Jennifer J. Kish, DETERT, James R., TREVIÑO, Linda Klebe ve EDMONDSON, Amy C. (2009), "Silenced by Fear: The Nature, Sources, and Consequences of Fear At Work", Research in Organizational Behavior, S.29, ss.1-31. 
GÖZÜM, Perihan - Covid-19 Salgını Döneminde Kamu Çalışanlarının Örgütsel Sessizlik Davranışlarının Kararlara Katılma ve İş Özerkliği Uygulamaları Üzerine Etkisi

GREENBERG, Jerald ve BARON, Robert A. (2003), Behaviour in Organisations: Understanding and Managing The Human Side of Work, Prentice Hall, Pearson Education.Inc. Upper Saddle River, New Jersey, $8^{\text {th }}$ Edition.

GÜLERYÜZ, Evrim ve AYDIN, Orhan (2006), "İş Kontrolü ve Kontrol İsteği İle Tükenmişlik ve Fiziksel Sağllk Arasındaki Illişkiler”, Türk Psikoloji Dergisi, S.21(58), ss.59-76.

HACKMAN, J. Richard ve OLDHAM, Greg R. (1975), "Development of the Job Diagnostic Survey", Journal of Applied Psychology, S.60(2), ss.159-170.

HOY, Wayne K. ve MiSKEL, Cecil G. (2010), Eğitim Yönetimi: Teori, Araştırma ve Uygulama (Çev. Selahattin Turan), Nobel Yayınları, Ankara.

KÂHYA, Cem (2013), "Dönüştürücü ve Etkileşimci Liderlik Anlayışları ile Örgütsel Sessizlik Arasındaki İlişkide Örgütsel Güvenin Rolü”, Yayınlanmamış Doktora Tezi, Atatürk Üniversitesi Sosyal Bilimler Enstitüsü, Erzurum.

KARACAOĞLU, Korhan ve CINGÖZ, Ayşe (2009), “İşgören Sessizliğin Kaynağı Olarak Liderlik Davranışı ve Örgütsel Adalet Algısı", 17. Ulusal Yönetim ve Organizasyon Kongresi Bildiriler Kitabı, Eskişehir, ss.21-23.

KARASAR, Niyazi (1999), Bilimsel Araştırma Yöntemi: Kavramlar, İlkeler, Teknikler. (8.baskı). Nobel Yayın Dağıtım, Ankara.

KESİCI, Mustafa (2014), “Aşçıların Mesleki Özerklikleri ile Yaratıcılık Süreci İlişkisi”, Yayımlanmamış Yüksek Lisans Tezi, Anadolu Üniversitesi Sosyal Bilimler Enstitüsü, Eskişehir.

KOLARSKA, Lena ve ALDRİCH, Howard (1980), "Exit, Voice, and Silence: Consumers' and Managers Responses to Organizational Decline”, Organization Studies, S.1(1), ss.41-58.

KUTANis, Pınar (2018), “Kendi Kendine Liderlik Tarzının Işs Tatmini ve Işs Özerkliği Üzerindeki Etkisini Belirlemeye Yönelik Bir Araştırma", Yayınlanmamış Yüksek Lisans Tezi, Hacettepe Üniversitesi Sosyal Bilimler Enstitüsü, Ankara.

LUMPKIN, Tom ve DESS, Gregory (1996), “Clarifying the Entrepreneurial Orientation Construct and Linking It to Performance", Academy of Management Review, S.21(1), ss.135-172.

MORGESON, Frederick ve HUMPHREY, Stephen (2006), "The Work Design Questionnaire (WDQ): Developing and Validating a Comprehensive Measure for Assessing Job Design and the Nature of Work", Journal of Applied Psychology, S.91(6), ss.1321-1339.

ÖZDOĞRU, Mehmet ve AYDIN, Bahri (2016), "The Relationship Among Elementary School Teachers' Participation in Decision-Making, Their Desire, and Motivation Levels", Abant İzzet Baysal Üniversitesi Eğitim Fakültesi Dergisi, S.12(2), ss.357-367.

PARNELL, John ve CRANDALL, William (2001), "Rethinking Participative Decision Making: A Refinement of The Propensity for Participative Decision Making Scale", Personnel Review, S.30(5), ss.523-535.

REEVE, Johnmarshall (2006), "Teachers as Facilitators: What Autonomy Supportive Teachers Do and Why Their Students Benefits", The Elementary School Journal, S.106(3), ss.225-236.

PREMEAUX, Sonya Fontenot ve BEDEIAN, Artur (2003), "Breaking The Silence: The Moderating Effects of Self-Monitoring in Predicting Speaking up in The Workplace", Journal of Management Studies, S.40(6), ss.1537-1562.

SONGUR KARAKURT, Tuğba (2020), "Öğretmenlerin Okullarda Alınan Kararlara Katılma Durumları ile Eleştirel Düşünme Eğilimleri Arasındaki İlişki”, Yayınlanmamış Yüksek Lisans Tezi, Gazi Üniversitesi Eğitim Bilimleri Enstitüsü, Ankara.

SPECTOR, Paul (1986), "Perceived Control by Employees: A Meta-Analysis of Studies Concerning Autonomy and Participation at Work", Human Relations, S.39(11), ss.1005-1016.

T.C. SAĞLIK BAKANLIĞI (2021), “Türkiyedeki Günlük Covid-19 Vaka Sayıları”, E-Haber, https://covid19bilgi.saglik.gov.tr/tr/haberler/turkiyedeki-gunluk-covid-19-vaka-sayilari.html (Erişim Tarihi: 15.12.2020). 
TKGM - TAPU VE KADASTRO GENEL MÜDÜRLÜĞÜ (2019), 2019-2023 Stratejik Plan, TKGM Yayını, Ankara, https://www.tkgm.gov.tr/sites/default/files/2020-10/stratejik_plan_2019_2023-guncelleme15.11.2019.pdf (Erişim Tarihi: 21.12.20202).

TORTOP, Nuri (1990), Yönetim Biliminin Temel İlkeleri, Türkiye ve Orta Doğu Amme İdaresi Enstitüsü Yayını, Ankara.

TURAN, Abdulmenaf ve HAMZA ÇELIKYYAY, Hicran (2020), "Türkiye'de Kovid-19 ile Mücadele: Politikalar ve Aktörler", Uluslararası Yönetim Akademisi Dergisi, S.3(1), ss.1-25.

URAL, Ayhan ve AKSAY, Orhan (2008), “Ortaöğretim Öğretmenlerinin Okulla İlgili Kararlara Katılımı”, Türk Eğitim Bilimleri Dergisi, S.6(3), ss.433-460.

URAS, Meral (1995), “Karara Katılmada Kabul Alanı Modeli”, Kuram ve Uygulamada Eğitim Yönetimi Dergisi, S.1(1), ss.121-130.

VAKOLA, Maria ve BOURADAS, Dimitris (2005), "Antecedents and Consequences of Organisational Silence: An Empirical Investigation", Employee Relations, S.27(5), ss.441-458.

WHO (2020a). https://www.who.int/csr/don/05-january-2020-pneumonia-ofunkown-cause-china/en/ (Erişim Tarihi: 21.12.2020).

WHO (2020b). http://www.euro.who.int/en/healthtopics/healthemergencies/coronavirus-covid-19/covid-19latest-updates (Erişim Tarihi: 21.12.2020).

WHO (2020c). http://experience.arcgis.com/experience/685d0ace521648f8a5beeeee1b9125cd, (Erişim Tarihi: 21.12.2020).

WILENSKY, Harold (1964), “The Professionalization of Everyone?”, American Journal of Sociology, S.70(2), ss.137-158.

YOLSAL, Murat (2020), "Yüksek Katılımlı Işs Sistemlerinin İnovatif Işs Davranışı Üzerindeki Etkisi: Işs Yeri Sosyal Desteğinin Aracılık Rolü”, Yayınlanmamış Doktora Tezi, İstanbul Ticaret Üniversitesi Sosyal Bilimler Enstitüsü, İstanbul.

ZHU, Hengbo, WEİ, Li ve NIU, Ping (2020), "The Novel Coronavirus Outbreak in Wuhan, China", Global Health Researchand Policy, S.5(6), ss.1-3. 